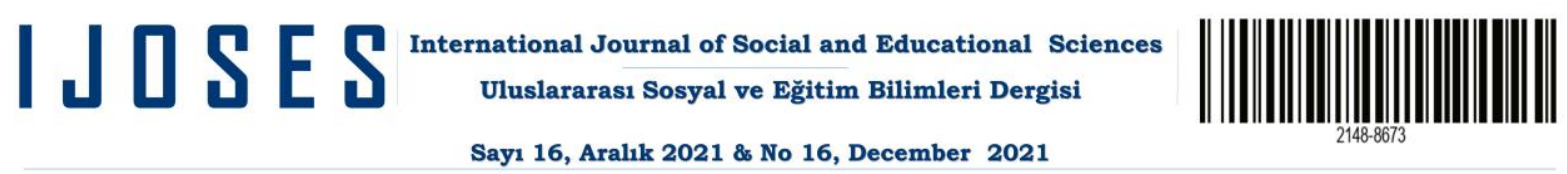

\section{İlkokul Birinci Sınıf Öğrencilerinin Okula Uyum ve Sosyal Yeterlik Düzeylerini Etkileyen Yordayıcıların İncelenmesi}

An Investigation of The Predictors that Affect First-Grade Students School Adaptation and Social Competence Levels

\author{
Mevlide Türker \\ Gaziantep Üniversitesi \\ meevliidee@gmail.com \\ ORCID ID: 0000-0002-0201-5869
}

\section{Erhan Tunç}

Doç. Dr.

Gaziantep Üniversitesi

erhantunc25@gmail.com

ORCID ID: 0000-0002-6328-8545

\author{
* \\ Makale Bilgisi / Article Information \\ Makale Türü / Article Type : Araştırma Makalesi \\ Geliş Tarihi / Received : 24 Ağustos 2021 \\ Kabul Tarihi / Accepted : 19 Ekim 2021 \\ Yayın Tarihi / Published : 15 Aralık 2021 \\ DOI Number : 10.20860/ijoses.986252
}

Bu makale, 2020 yılında Gaziantep Üniversitesi Eğitim Bilimleri Enstitüsü Temel Eğitim Anabilim Dalı'nda sunulan “İlkokul Birinci Sını Öğrencilerinin Okula Uyum ve Sosyal Yeterlik Düzeylerini Etkileyen Yordayıcıların İncelenmesi" adlı yüksek lisans tezinden türetilmiştir.

$$
*
$$

\section{Kaynak Gösterme / Citation}

Türker, M. \& Tunç, E. “ílkokul Birinci Sınıf Öğrencilerinin Okula Uyum ve Sosyal Yeterlik Düzeylerini Etkileyen Yordayıcıların İncelenmesi". Uluslararası Sosyal ve Ĕ̆itim Bilimleri Dergisi, 16 (2021): 104-122. 


\title{
İlkokul Birinci Sınıf Öğrencilerinin Okula Uyum ve Sosyal Yeterlik Düzeylerini Etkileyen Yordayıcıların İncelenmesi
}

\author{
An Investigation of The Predictors that Affect First-Grade Students School Adaptation and Social \\ Competence Levels
}

\section{Mevlide Türker \& Erhan Tunç}

$\ddot{O} z$

Bu araştırmada, ilkokul birinci sınıf öğrencilerinin okula uyum ve sosyal yeterlik düzeylerini etkileyen yordayııılar incelenmiştir. Araştırma betimleyici tarama modeli esas alınarak yürütülmüştür. Araştırmanın çalışma grubu, 2019-2020 öğretim yılında Kilis ilindeki ilkokullarda öğrenim gören ve sınıf öğretmeni tarafından okula uyum güçlüğü olduğu gözlenen, $79^{\prime} u$ kız ve 100'ü erkek olmak üzere 179 ilkokul birinci sınıf öğrencisinden oluşmaktadır. Araştırmada veri toplamak için Sosyal Yeterlik ve Okula Uyum Ölçeği ve kişisel bilgi formu kullanılmıştır. Araştırma sonucunda cinsiyetin okula uyum düzeyi için anlamlı bir yordayıcı olduğu bulgulanmıştır. Öğrencilerin okul öncesi eğitim alma durumunun akran tercihli davranış, öğretmen tercihli davranış ve okula uyum düzeyi için anlamlı düzeyde bir yordayıcı olmazken; ailenin öğretmenle yeterince iş birliğine girip girmemesinin akran tercihli davranış, öğretmen tercihli davranış ve okula uyum düzeyi için anlamlı yordayıcı olduğu görülmüştür. Öğrencilerin travmatik bir yaşantısının olup olmama durumunun ise akran tercihli davranış için anlamlı bir yordayıcı olduğu bulgulanmıştır.

Anahtar Kelimeler: Okula Uyum, Sosyal Yeterlik, İlkokul Birinci Sınıf Öğrencileri.

\section{Abstract}

In this study, the predictors that affect the school adjustment and social competence levels of first grade primary school students were examined. The research was carried out based on the descriptive survey model. The study group of the research consists of 179 primary school first grade students, 79 girls and 100 boys, who were studying in primary schools in Kilis in the 2019-2020 academic year and were observed to have difficulties in adapting to school by the classroom teacher. Social Competence and School Adjustment Scale and personal information form were used to collect data in the study. As a result of the research, it was found that gender is a significant predictor of school adjustment level. While the pre-school education status of the students is not a significant predictor of the level of peer preferential behavior, teacher preferred behavior and school adjustment; It has been seen that whether the family cooperates with the teacher sufficiently or not is a significant predictor of the level of peer preferred behavior, teacher preferential behavior and school adjustment. It has been found that whether students have a traumatic experience or not is a significant predictor of peerpreferred behavior.

Keywords: School Adjustment, Social Competence, Primary School First Year Students. 


\section{Extended Summary}

\section{Purpose and Significance:}

The effect of starting primary school and primary school on social skills is indisputably important (Uz Baş, 2003). Kılıç and Gedik (2019) emphasize that primary school is a basis for the education that the child will get out of the play period, meet with life, participate in planned and programmed teaching activities for the first time, and will receive education in the future; Bartan (2019), on the other hand, stated that the most important period in the education system is the primary school, which has a great influence in the following periods. Although there are studies (Sungur, 2010; Türkyılmaz, 2018; Yoleri and Tanış, 2014; Zorbaz, 2016) in the related literature examining the factors affecting the primary school adjustment and social competence levels of children in this period, no research has been found on the predictors of school adjustment and social competence of these factors. In this study, it was tried to determine to what extent the variables studied in the literature are related to school adjustment and social competence, as a predictor. Thus, studies to be carried out in order to develop, support and complement school adaptation and social skills were also shed light on. In the process of adaptation to school, it is very important for both the teacher and the family to know the characteristics of children who have just started school, in terms of predetermining risky situations and creating effective adaptation programs (Başaran, Gökmen, \& Akdağ, 2014). In this context, as a result of this research, by determining the variables that are significantly predictive of the child's school adaptation and social skills, it will contribute to the development of preventive and developmental orientation programs, etc., for children who have problems in adapting to school in primary schools.

\section{Methodology:}

The study group of this research, which was designed as a relational screening model, consists of a total of 179 students, 79 girls and 100 boys, who were determined by convenient sampling among the students studying at the first grade level of primary school in the city center of Kilis in the 2019-2020 academic year. Social Competence and School Adjustment Scale and Personal Information Form were used to collect data in the research. The data obtained from the teacher-preferred social behavior, peerpreferred social behavior, and school adjustment behavior subscales of the scale, and the variables of gender, pre-school education status, family cooperation with the teacher, and whether there is trauma experience as predictors of school adjustment were added to the analyzes. 72 first grade teachers, who have students with suitable characteristics for the study group of this research, were reached through face-to-face or online forms and were provided to answer the data collection tools. The obtained data were analyzed in SPSS 24.0 package program with analysis techniques suitable for the characteristics of the data set.

\section{Results, discussion and conclusion:}

As a result of the research; It was found that gender was a significant predictor of school adjustment, but not a significant predictor of peer-preferred behavior and teacher-preferred behavior. When the literature is examined; While there are studies (Arabacıŏglu, 2019; Arslan, 2016; Çökük, 2019) stating that the scores of peer preferred behavior, teacher preferential behavior and school adjustment level do not differ significantly according to gender, it is seen that there are studies that state that the scores differ significantly in the direction of girls (Arabacioğlu, 2019; Geçin, 2016; Güler, 2016 (and boys) (Başaran, Gökmen ve Akdağ, 2014; Taner ve Başal, 2005. As a result of this research, the fact that gender is a significant predictor of school adjustment can be explained by both temperament and social identity related to gender.

It has been observed that the students' pre-school education status is not a significant predictor of peer preferential behavior, teacher preferential behavior and school adjustment level. When the relevant literature is examined, contrary to the findings obtained from this research; There are studies 
(Çökük,2019; Demirci, 2019; Ertürk, 2018) in which pre-school education status has a significant effect on peer preferential behavior, teacher preferential behavior and school adjustment level. In this study, the fact that pre-school education was not a significant predictor of screen preference, behavioral teacher preference, behavior and school adjustment can be explained in relation to the pre-school education conditions of the research group.

As a result of the research; It has been concluded that whether the family cooperates with the teacher sufficiently or not is a significant predictor of peer preferred behavior, teacher preferential behavior and school adjustment level. When the relevant literature is examined; While there are studies(Bekyürek, 2008; Gürşimşek, 2010; Özcan and Aydoğan, 2014) in this direction, there are also studies(Gürşimşek, 2003; Zorbaz, 2016) reporting different results. This finding obtained as a result of the research can be explained by the effect of cooperation between the family and the teacher, since the child is going through one of the cycles of separation from the family during the beginning of primary school.

It was found that whether students had a traumatic experience or not was not a significant predictor of teacher-preferred behavior and school adjustment, but was a significant predictor of peer-preferred behavior. When the relevant literature is examined, the study conducted by Okutan (2017) shows that students' having a traumatic experience affects school adjustment. The result obtained in the study can be explained as the child's adaptation to school will be difficult with the effect of multiple crisis, which is formed by the addition of a traumatic experience to the school starting crisis experienced during the period when the child starts primary school.

\section{Giriş}

Bireyin okul öncesi eğitimin ardından ilk eğitimi aldığı yer ilkokuldur. İlkokula başlayan çocuğun bir toplumun üyesi olduğunu kabul etmesi, toplumdaki davranışların bilincine varması ve bu topluma uyum sağlaması eğitim aracılığıyla meydana gelmektedir.

İlkokula başlayan öğrencinin yeni bilgiyi oluşturup öğrenebilmesi için ön bilgilere yani bir hazırbulunuşluğa sahip olması gerekmektedir. İlkokul çocuklarının hazırbulunuşluğunu ve okula uyumunu kazandırabilmek adına okul öncesi eğitim büyük önem taşımaktadır. Okul öncesi eğitimin verdiği hazırbulunuşluk ile çocuk ilkokula yumuşak bir geçiş sağlayabilmektedir. Bu yumuşak geçiş aracılığıyla ilkokula başlayan öğrencinin okula uyumu da kolaylaşabilir. Ancak çocuğun hazırbulunuşluğunu etkileyen birçok faktör vardır. Bunlar; fizyolojik, bilişsel, duygusal ve çevresel faktörlerdir. İlkokula başlayan çocuğun; yaşı, sağlı̆̆ı, cinsiyeti, bütün duyu organları ve zekasının birbiriyle uyum içinde çalışarak öğrenim etkinliğine katılması beklenmektedir. Aynı zamanda bu dönemde kalem tutabilme, sırada uygun şekilde oturabilme, ayaklarını yazı yazarken yere tam olarak basabilme gibi fizyolojik faktörlerde etkili olabilmektedir. Bilişsel olarak da çocuğun ilkokula başlarken yazı yazma, okuma, düşünme ve problem çözme gibi zihinsel yapılara sahip olması gerekmektedir (Tuğluk ve Ayhan, 2019). İlkokul birinci sınıftaki çocuğun kendini tanıması, hangi durumda nasıl tepkiler göstereceğini bilmesi, dil becerisini kullanabilmesi, gerek akranları gerekse yetişkinlerle iyi bir iletişim kurabilme becerisine ve özdenetime sahibi olması gerekmektedir (Teke, 2010). İlkokula başlayan öğrencilerin öğrenme yeteneğinin gelişiminde çevre de önemli bir faktördür. Çevre denilince ise çocuğun en yakınındaki aile akla gelebilir. Anne babanın eğitim düzeyi, ekonomik durumu, evdeki iletişimi, okula karşı tutumu, çocuğun okula hazırbulunuşluğunu etkileyen önemli bir diğer faktördür. İlkokula hazırbulunuşluğu saptayan bu faktörler okula uyumda da önemli rol oynamaktadır (Polat ve Akyol, 2019; Sungur, 2010; Teke, 2010; Tuna ve Kaçar, 2005).

Bireyin yaşamı doğumundan itibaren birçok gelişim dönemine ayrılmaktadır. Her gelişim dönemin gerektirdiği belirli görevler vardır. Son çocukluk döneminin görevi ise okula başlamaktır. Çocuğun okula başlaması ile birlikte rolü ve kimliği değişmektedir (Akay ve Ceylan, 2019). Bu değişim 
sonucunda çocuğun yeni girdiği çevrenin taleplerine ve bulunduğu yeni ortamın kurallarına uyum sağlaması beklenmektedir. Okula uyum, çocuğun tanıştığı ilkokulun kendisinden isteklerine karşı gösterdiği sosyal, davranışsal ve akademik tepkilerdir (Canbulat, 2007). İlkokul birinci sınıfa başlayan çocuğun yerine getirmesi gereken birçok sorumluluk olduğu için bunları edinebileceği bir okul öncesi eğitimine ihtiyacı vardır (Polat ve Akyol, 2019). Ancak ilkokul okul öncesinden farklı kurallara sahip olan bir kurumdur. Okul öncesi dönemde çocuk yaşının gereği olarak oyun ağırlıklı eğitimler görürken, ilkokula başlayınca karşılaştı̆̆ temel yazma ve matematik gibi eğitimler çocukta katı sorumluluk gibi algılanabilir. Bu durumu en aza indirgeyebilmek için sınıf ortamı çocuk için eğlenceli ve çocuğun ilgisini çekebilecek şekilde düzenlenebilir. Okula uyumda problem sadece bireyden kaynaklanmamaktadır. Çocuk ile birlikte aile ve okul gibi değişkenler de okula uyum sürecini etkilemektedir (K1zıltaş, 2009; Özcan, 2012; Özcan ve Aydoğan, 2014). İlkokula başlayan çocuk okula uyumunu problemsiz bir şekilde gerçekleştirmiş ise dersler ile tanıştığı bu ortamda daha dikkatli, daha aktif ve daha başarılı olmaktadır. Uyum sürecinde sorun yaşamayan öğrencinin öz güveni yüksek, eğitim-öğretim ortamına aktif katılabilen ve buna bağlı olarak akademik başarısı da yüksek olabilmektedir. Çocuğun okulu sevmesi okula uyumunun bir göstergesidir (Geçin, 2016). Her öğrenci aynı bireysel özelliklere sahip olmadığı için bu süreçte okulu sevip uyum saylayan öğrencilerin yanı sıra uyum problemi yaşayan birçok öğrenci de vardır. Bu uyum problemlerin nedenlerini anlamadan hazır olmadığı bir ortama bırakılmış öğrenci, okula karşı olumsuz tutum geliştirerek ve bütün eğitim hayatı etkilenebilmektedir. Kısacası okula uyum sürecinde sorun yaşayan bir çocuğun sorunu düzeltilmeden devam edilirse, çocuk ilerideki yaşamında akademik ve duygusal açıdan sorunlar yaşayabilir.

Okula uyum aynı zamanda çocuğun sosyal uyumu demektir. Çocuk okula yeni başladığı dönemde sosyalleşme ile ilgili temel kazanımları henüz kazanamadan önce, yeni tanıştığı ortam olan sınıfa uyumunda zorluklar yaşayabilmektedir. Bu zorlukları yumuşatarak kolay geçişler sağlanabilmesi için birçok paydaş rol oynamaktadır. Aile, okul ve çocuğun kendisi ile ilgili faktörler okula uyumu etkilemektedir. Okula başlayacak olan çocuğun; fiziksel ve motor, sosyal ve duygusal, bilişsel ve dil, öz bakım becerilerine (giyinme, öz bakım, tuvalet kontrolü, sorumluklarını bilme, sabırlı olma, kendini koruma, arkadaşlık kurma, kendisini ifade etme, sırada oturma, yönergelere uyma, dikkat olma) sahip olması gerekmektedir (Dirlik, 2014). Çocuğun sosyalleşmeyi öğrendiği ilk çevre (Sungur, 2010) olan ebeveynlerin, çocuğun davranışları karşısında takındıkları tutumlar da, ilkokul birinci sınıfa başlandığında okula uyumunu etkileyen faktörlerdendir.

Çocuğun çevresini inceleyen ekolojik yaklaşım açısından da okula uyumun incelenmesi gerekebilir. Canlıların birbiri ve çevresi ile olan ilişkisini inceleyen bilim dalı olan ekoloji; bireyin davranışına etki eden birey, aile, toplum gibi iç ve dış güçlerin etkileşimleri açıklayan sistem ise ekolojik sistem yaklaşımı olarak tanımlanmaktadır (Zorbaz, 2016). Yaklaşıma göre bir çocuğun gelişimini incelemek istiyorsak geniş çevrenin etkileşimini incelememiz gerekmektedir (Ryan, 2001). Herhangi bir sistemde değişim meydana geldiği zaman diğer sistemler ile mutlaka alakalı olabileceği düşünülmektedir. Bu nedenle ekolojik yaklaşım sistemi çocuğun en yakın çevresinden (mikrosistem, mezosistem, ekzosistem, makrositem ve kronosistem) uzağına doğru genişlediği sistemde ele alınmaktadır (Zorbaz, 2016).

Ekolojik yaklaşım gibi sosyal yeterlikte ilkokula başlayan öğrencilerin okula uyumunu etkileyen faktörlerden biridir. Bireyin topluma uyum sağlayabilmek ve toplumda varlığını sürdürebilmek için birtakım sosyal becerilere sahip olması gerekmektedir. Sosyal yeterlik ise bireyin bu becerileri kullanabilmesidir. Sosyal yeterlik, çocukluk dönemi için de oldukça önemli bir kavramdır. Taş̧̧ı (2013) sosyal açıdan yeterli olan çocuklar toplumda ve sinıfta mutlu, huzurlu, akranlarıla başarılı ilişkilere sahip olduklarını; ancak sosyal açıdan yetersiz olan çocukların mutsuz, akademik başarısı düşük ve akran grubu tarafından dışlandığını ifade etmiştir. İlkokulda sosyal yeterliği etkileyen faktörler çocuğun yaşı, aile, kardeş ilişkileri, akran grubu ile çocuk ve öğretmen ilişkisidir. Okula başlayan çocuk aile ortamından ilk kez ayrılarak yeni bir çevre ile tanışır. Çocuk yaşı itibariyle bu dönemde oyun ve arkadaş 
grupları ile daha ilgilidir. Bu nedenle ebeveynler ve öğretmen, çocuğu oyun ortamında gözlemleyerek sosyalleşmesi hakkında bilgi sahibi olabilir. Ailenin ekonomik durumu, genişliği, çocuk sayısı, ebeveynlerin çocukla ilgilenme durumları çocuğun hem akademik başarısını hem de sosyal yeterliğini etkileyen faktörlerdendir. Kardeşler ile olan ilişkilerde sosyal yeterliği etkilemektedir (Sungur, 2010). Kardeş sayısının fazla olması çocukta sorumluluk duygusunu edinmesini sağlamakta ve çocuğun sosyalleşmesine katkı sağlamaktadır (Deniz, 2016). Doğum sırası da çocuğun sosyal yeterliklerini etkilemektedir. İlk çocuk genelde aile tarafından daha çok ilgi gördüğü için akran grubu iletişiminde eksiklik yaşarken, son çocuklar da çocukluktan çıkamama ve geç olgunlaşma, ortanca çocuklarda ise bağımsız yetişme gibi özellikler görülebilir (Deniz, 2016). Ailenin tek çocuğu olmak Ailenin ilgisi sürekli çocuğun üzerinde olduğu için çocukta bağımlılık ve benmerkezcilik duyguları gelişirken (Öztabak, 2019), ailenin en küçük çocukları ise popüler, çıkarcı, bencil tavırlara sahip olması ve sorumluluk verilmesinden kaçınılarak serbest yetiştirilmesinden dolayı ilkokula başladığında okulun getirdiği sorumluluklar karşısında güçlük yaşayabilmektedir. Bir çocuğun sosyalleşmesi, gelişmesi ve kendisini tanıması açısından akran grupları ile kurduğu arkadaşlıklar da önemli rol oynamaktadır. Çocuk, akran grubu ile vakit geçirdikçe aileye olan bağlılığ azalacak ve bu durum okula uyumuna katkı sağlayarak sosyalleşmesini etkilemektedir. Çocuğun okula karşı olumlu veya olumsuz duygular geliştirmesinde en etkili kişi olan birinci sınıf öğretmeni ise; tüm öğrencilerini tanımalı, farklı yöntem ve teknikler benimsemeli, sevecen, hoşgörülü, temel becerilerin öğretimi hakkında yeterince bilgi sahibi olmalıdır (Baştuğ ve Hiğde, 2019).

\section{Yöntem}

\section{Araştırmanın modeli}

İlkokul birinci sınıf öğrencilerinin okula uyum ve sosyal yeterlik düzeylerini etkileyen yordayıcıların incelendiği bu araştırmanın modeli, nicel araştırma desenlerinden birisi olan ilişkisel tarama modelidir.

\section{Örneklem}

Araştırmanın çalışma grubu, Kilis il merkezinde, 2019-2020 eğitim-öğretim yılında, ilkokul birinci sınıf düzeyinde öğrenime devam eden 179 öğrenciden oluşmaktadır. Çalışma grubuna dahil edilecek öğrenciler seçkisiz olmayan örnekleme yöntemlerinden uygun örnekleme ile belirlenmiştir. Araştırmaya dahil edilecek öğrenciler belirlenirken; Kilis iline bağlı ilkokullarda çalışan birinci sınıf öğretmenleri arasından, sınıfinda okula uyum sorunu yaşadığı düşünülen öğrencilerin her biri için öğretmenlerin “Okula Uyum ve Sosyal Yeterlik Ölçeği”ni doldurmaları istenmiştir. Böylece 180 öğrenciye ulaşılarak analize dahil edilecek çalışma grubu belirlenmiştir. Analizler öncesinde bir öğrencinin uç değer olması nedeniyle analizden çıkarılması sonucu araştırma 79'u kız ve 100'ü erkek olmak üzere 179 öğrencinin dahil olduğu analizler yapılarak ilerlemiştir.

\section{Veri toplama aracı}

Araştırmada, okula uyum güçlüğü yaşayan öğrencilerin sosyal yeterlik ve okula uyum düzeylerini belirlemek amacıyla Walker ve McConnell (1995) tarafından geliştirilen, Uz Baş (2003) tarafından Türkçe'ye uyarlaması yapılan Sosyal Yeterlik ve Okula Uyum Ölçeği kullanılmıştır. Ayrıca, araştırmada ihtiyaç duyulan bazı demografik değişkenleri belirlemek amacıyla araştırmacı tarafından hazırlanan kişisel bilgi formu kullanılmıştır.

\section{Sosyal Yeterlik ve Okula Uyum Ölçeği}

Walker ve McConnell (1995) tarafından geliştirilen, Uz Baş (2003) tarafindan Türkçeye uyarlaması yapılan Sosyal Yeterlik ve Okula Uyum Ölçeği, sosyal yeterlik terimi altında sınıflandırılan iki temel uyum alanını ölçecek şekilde hazırlanmıştır. Bunlar uyuma yönelik sosyal davranış ve kişilerarası sosyal yeterliktir. Ölçeğin üç alt ölçeği ve toplam 43 maddesi bulunmaktadır. Öğretmen tercihli sosyal davranış 
alt ölçeği, akran ilişkilerinde duyarlık, empati, iş birliği, kendini kontrol ve sosyal açıdan olgunluk gibi öğretmenlerce oldukça değer verilen davranışları içeren 16 maddeden oluşmaktadır. Akran tercihli sosyal davranış alt ölçeği, serbest oyun zamanlarındaki akran dinamiklerini ve sosyal ilişkilerini yöneten sosyal davranış biçimlerine ilişkin akran değerlerini yansıtan 17 maddeden oluşmaktadır. Okula uyum davranışı alt ölçeğinde, eğitimsel ortamların yönetilmesiyle ilgili doğal öğretmen beklentilerini yansıtan 10 maddeyi içermektedir. Ölçek, 43 maddeden oluşan 5'li likert tipi bir ölçektir. Asla (1) ile hemen hemen her zaman (5) arasında dağılan ve öğretmenin öğrenci hakkındaki gözlemlerinin değerlendirildiği bir ölçme aracıdır. Her bir alt ölçekten elde edilen 3 farklı puan ve bu alt ölçeklerin toplamından elde edilen toplam puan olmak üzere 4 farklı puan elde edilmektedir. Elde edilen toplam puan, bir öğrencinin sosyal yeterlik ve okula uyumuna dair genel bir indeks sağlamaktadır. Ölçeğin yapı geçerliği kapsamında yapılan faktör analizine göre, toplam varyansın \% 71'ini açıklayan beş faktör elde edilmiştir. İkinci faktör analizi işlemiyle, ölçeğin orijinal faktör yapısı dikkate alınarak, faktör sayısı toplam varyansın \% 65'ini açıklayan üç faktöre indirgenmiștir. Toplam ölçek için ölçeğin madde-toplam korelasyonları değerleri 0.32 ile 0.82 arasında bulunmuştur ( $\mathrm{Uz}$ Baş, 2003). Bu araştırmada ölçeğin güvenirliğini test etmek için Cronbach alfa güvenirlik katsayısı hesaplanmıştır. Analizler sonucunda, Cronbach alfa güvenirlik katsayısı öğretmen tercihli sosyal davranış alt ölçeği için 0.92 , akran tercihli sosyal davranış alt ölçeği için 0.93 , okul uyuma alt ölçeği için de 0.88 olarak bulunmuştur. Ölçeğin tamamına ait Cronbach alfa güvenirlik katsayısı da 0.96 bulunmuştur. Ölçeğin tamamı ve alt ölçeklerine ait güvenirlik katsayıları, ölçme aracının yüksek güvenirliğe sahip olduğunu göstermektedir (Büyüköztürk, 2012).

\section{Öğrenci Kişisel Bilgi Formu}

Literatürde okula uyum sorunu yaşayan öğrencilerin profilinin belirlenmeye çalışıldığı araştırmalar incelenerek uyumu güçleştiren ve bu araştırmada yordayıcı faktörler olduğu düşünülen değişkenlerin sorulduğu kişisel bilgi formu, araştırmacı tarafından hazırlanmıştır. Bu form, öğrencilerin cinsiyeti, okul öncesi eğitim alma durumu, ailede çocuğu travmatize eden bir durumun varlığ (bilgi formunda çocuğun etkilendiği bir kötü deneyim olup olmadığ 1 sorulmuştur. Boşanma, şiddet, kaybolma, kayıp yaşama...vb), ebeveynin öğretmen ile yeterince iş birliğinde olma durumuna ilişkin dört sorudan oluşmaktadır.

\section{Deneysel İşlem Süreci}

Veri toplama sürecinde, gerekli izin prosedürleri tamamlandıktan sonra, araştırmanın çalışma grubu olacak olan ve öğretmeni tarafından uyum sorunu yaşadığı düşünülen öğrencilere ulaşmak için öğretmenlere ön görüşme yapılmıştır. Bu araştırma için uygun özelliklere sahip öğrencileri olan 72 birinci sınıf öğretmenine yüz yüze veya Google formlar aracılı̆̆ıyla ulaşılmış ve "okula uyum ve sosyal yeterlik ölçeği”"ni doldurmaları sağlanmıştır. Böylece 180 okula uyum sorunu yaşayan birinci sınıf öğrenci ile ilgili veriye ulaşılmıştır.

\section{Verilerin analizi}

Veri toplama araçlarından elde edilen veriler, bilgisayar ortamına aktarılarak analizlere geçmeden önce veriler analize hazır hale getirilmiştir. Veriler, SPSS 24.0 programı kullanılarak analiz edilmiştir. Analiz öncesinde kayıp veriler incelenmiş, ardından uç değerlere bakılmış ve $-3,+3$ aralığı dışında kalan 1 form veri setinden çıkarılmıştır. Ölçeklerden alınan puanların dağılımlarının normallik yönünden incelenmesi için Kolmogrov- Smirnov testi ("akran tercihli davranış" için .000, "öğretmen tercihli davranış" için .024, "okul uyumu” için .007) yapılarak basıklık ve çarpıklık katsayıları hesaplanmıştır. Çarpıklık değerleri "akran tercihli davranış" için .707, "öğretmen tercihli davranış" için .758, "okul uyumu" için .406 bulunmuştur. Kullanılacak olan alt boyutlar için çarpıklık ve katsayıları incelendiğinde $-1,+1$ aralığında kaldığg görülmüştür. Böylece dağılımın normalden sapma göstermediği belirlenmiştir. Ardından veri setinin regresyon analizi için gerekli varsayımları karşılayıp karşılamadığı 
incelenmiştir: Çoklu bağlantı problemine ilişkin yapılan analizler, değişkenler arası korelasyon değerleri, VIF değerleri ve tolerans değerleri incelenerek yapılmıştır. "Veri setinde yer alan tüm ikili korelasyonlar dikkate alındığında, korelasyonun .90'dan büyük, VIF değerlerinin 10'dan büyük ve tolerans değerlerinin .10'dan küçük olduğu durumlarda çoklu bağlantı probleminden söz edilebilir" (Çokluk, Şekercioğlu ve Büyüköztürk, 2012: 35). Değişkenlere ait tolerans ve VIF değerleri Tablo 1'de verilmiştir.

Tablo 1. Değişkenlere ait Tolerans ve VIF Değerleri

\begin{tabular}{lcc}
\hline Değişkenler & Tolerans & VIF \\
\hline Akran Tercihli Davranış & .380 & 2.63 \\
Öğretmen Tercihli Davranış & .333 & 2.99 \\
Okula Uyum & .510 & 1.96 \\
\hline
\end{tabular}

Tablo 1'de görüldüğü üzere bu araştırmada değişkenlere ait tüm VIF değerleri 10'dan küçük ve tolerans değerleri .10'dan büyüktür.

"Regresyon analizi için kategorik değişkenler "dummy değişken” olarak yeniden kodlandıktan sonra analize dahil edilmektedir" (Büyüköztürk, 2012: 92). Travma, iş birliği, cinsiyet, okul öncesi eğitim değişkenleri kategorik değişken oldukları için dummy değişken olarak kodlandıktan sonra analize dahil edilmiştir. Çoklu regresyon analizi ve lojistik regresyon analizi teknikleri kullanılarak araştırma verileri yorumlanmıştır. Araştırmanın demografik değişkenlerine ilişkin betimsel veriler Tablo 2'de verilmiştir.

Tablo 2. Araştırmanın Demografik Değişkenlerine İlişskin Betimsel Veriler

\begin{tabular}{|c|c|c|c|c|c|}
\hline Cinsiyet & $\mathrm{n}$ & $\%$ & Ailenin iş birliği & $\mathrm{n}$ & $\%$ \\
\hline $\mathrm{K} 1 \mathrm{Z}$ & 79 & 44.1 & Yeterli & 62 & 34.6 \\
\hline Erkek & 100 & 55.9 & Yetersiz & 117 & 65.4 \\
\hline Okul öncesi eğitim alıp almadığ & $\mathrm{n}$ & $\%$ & Travma deneyimi var mı? & $\mathrm{n}$ & $\%$ \\
\hline Ald1 & 74 & 41.3 & Var & 75 & 41.9 \\
\hline Almad 1 & 105 & 58.7 & Yok & 104 & 58.1 \\
\hline
\end{tabular}

Tablo 2 incelendiğinde, çalışma grubunu oluşturan öğrencilerin \%44.1 (n=79)'i kı, \%55.9 ( $\mathrm{n}=100)$ 'u erkek; \%41.3 ( $\mathrm{n}=74$ )'ünün okul öncesi eğitim aldı̆̆ı, \%58.7 ( $\mathrm{n}=105)$ 'sinin okul öncesi eğitim almadı̆̆1; \%34.6 (n=62)'sının ailesinin öğretmen ile yeterince iş birliğine girerken, \%65.4 (n=117)'ünün ailesinin öğretmenle yeterince iş birliğine girmediği; \%41.9 $(\mathrm{n}=75)$ 'unun travma deneyiminin var olduğu, \%58.1 (n=104)'inin travma deneyimi olmadığı görülmektedir.

\section{Bulgular}

$\mathrm{Bu}$ bölümde, öncelikle araştırmanın veri toplama araçlarından elde edilen ölçek puanlarına yani yordanan değişkenlere ait betimsel istatistik değerleri verilmiştir. Ardından akran tercihli davranış, öğretmen tercihli davranış ve okula uyum düzeylerini yordayan değişkenleri belirlemek amaciyla travma, iş birliği, cinsiyet ve okul öncesi eğitim değişkenlerine ilişkin çoklu regresyon analizi sonuçlarına yer verilmiştir. Daha sonra akran tercihli davranış, öğretmen tercihli davranış ve okul uyumu değişkenlerinin travma yaşayan ve yaşamayan, iş birliği yapan ve yapmayan ve okul öncesi eğitim alan ve almayan öğrencileri doğru sınıflandırma düzeyini belirlemek amacıyla yapılan lojistik regresyon analizi sonuçları açıklanmıştır. 


\section{Araştırmanın Veri Toplama Araçlarına İlişkin Betimsel Analizleri}

Araştırmada kullanılan Öğrenci Kişisel Bilgi Formu ve Sosyal Yeterlik ve Okula Uyum ölçeğinin alt boyutları olan "akran tercihli davranış", "ögretmen tercihli davranış" ve "okula uyum" boyutlarından elde edilen puanlara, yani yordanan (bağımlı) değişkenlere ilişkin betimsel istatistikler yapılmış ve elde edilen bulgular Tablo 3'te verilmiştir.

Tablo 3. Yordanan değişkenlere ilişskin betimsel istatistikler

\begin{tabular}{lccccc}
\hline Değişkenler & $\mathrm{n}$ & Min & Max & X & Ss \\
\hline Akran Tercihi & 179 & 17.00 & 74.00 & 37.03 & 9.84 \\
Öğretmen Tercihi & 179 & 16.00 & 70.00 & 34.48 & 9.54 \\
Okula Uyum & 179 & 11.00 & 46.00 & 24.68 & 6.66 \\
\hline
\end{tabular}

Tablo 3 incelendiğinde akran tercihli davranış alt boyutun puan ortalamasının 37.03, öğretmen tercihli davranış alt boyutunun puan ortalamasının 34.48, okul uyumu alt boyutunun puan ortalamasın da 24.68 olduğu görülmektedir. Tablodaki veriler incelendiğinde her bir alt ölçekten elde edilen ortalama puanların, alınabilecek maksimum puanların yaklaşık olarak grubun \%50. noktasında (ortanca, medyan) puanlar olduğu görülmektedir. Dağılımlara ait değişim kat sayıları incelendiğinde (sırasıyla; $26.573 ; 27.668 ; 26.985)$ de alt ölçek puanlarının benzer düzeyde farklılaştığı söylenebilir.

\section{Araştırmanın Yordamaya İlişkin Regresyon Analizleri}

Araştırmada kullanılan Öğrenci Kişisel Bilgi Formu ve Sosyal Yeterlik ve Okula Uyum Ölçeğinin alt boyutları olan "akran tercihli davranış", "öğretmen tercihli davranış" ve "okula uyum” düzeylerin araştırmanın bağımsız değişkenleri olan öğrencinin travmatik bir yaşantısının olup olmadığı, ailenin öğretmenle yeterince iş birliğine girip girmediği, öğrencinin cinsiyeti ve okul öncesi eğitim alıp almadı̆̆ 1 değişkenleri tarafından ne düzeyde yordandığına ilişkin regresyon analizleri yapılmış ve elde edilen bulgular Tablo 4, Tablo 5 ve Tablo 6'da verilmiştir.

Araştırmada kullanılan Öğrenci Kişisel Bilgi Formu ve Sosyal Yeterlik ve Okula Uyum Ölçeğinin alt boyutlarından biri olan "akran tercihli davranış"ın yordanmasına ilişkin çoklu regresyon analizi yapılmış ve sonuçlar Tablo 4'te verilmiştir.

Tablo 4. Akran Tercihli Davranış Düzeyinin Yordanmasına İlişkin Çoklu Regresyon Analizi Sonuçları

\begin{tabular}{lccccc}
\hline \multicolumn{1}{c}{ Değişken } & $\mathrm{B}$ & Standart Hata B & $\beta$ & $\mathrm{T}$ & $\mathrm{P}$ \\
\hline Sabit & 39.328 & 1.950 & & 20.170 & .000 \\
Travma & 3.746 & 1.445 & .188 & 2.593 & $.010^{*}$ \\
İş birliği & -5.064 & 1.505 & -.245 & -3.366 & $.001^{*}$ \\
Cinsiyet & .169 & 1.396 & .009 & .121 & .904 \\
Okul öncesi eğitim & -2.131 & 1.425 & -.107 & -1.496 & .137 \\
\hline
\end{tabular}

$\mathrm{R}=.27 \mathrm{R}^{2}=.14 * \mathrm{p}<.05$

Tablo 4 incelendiğinde araştırmanın bağımsız değişkenleri olan öğrencinin travmatik bir yaşantısının olup olmadığı, ailenin öğretmenle yeterince iş birliğine girip girmediği, öğrencinin cinsiyeti ve okul öncesi eğitim alıp almadığı değişkenlerinin akran tercihli davranıştaki varyansın \%14'ünü açıkladığı görülmektedir. Standardize edilmiş regresyon katsayısına $(\beta)$ göre, akran tercihli davranış düzeyi üzerindeki göreli önem sırası; iş birliği $(\beta=-.245)$, travma $(\beta=.188)$, okul öncesi eğitim $(\beta=-.107)$ cinsiyet $(\beta=-.009)$, olarak sıralanmaktadır. Tabloda regresyon katsayılarının anlamlılığına ilişkin t testi sonuçlarına bakıldığında da; iş birliği $(\mathrm{t}=-3.366, \mathrm{p}<.05)$ ve travma $(\mathrm{t}=2.593, \mathrm{p}<.05)$ değişkenlerinin akran tercihli davranış üzerinde anlamlı yordayıcılar olduğu; ancak cinsiyet ( $\mathrm{t}=-.121, \mathrm{p}>.05)$ ve okul 
öncesi eğitim ( $\mathrm{t}=-1,496, \mathrm{p}>$.05) değişkenlerinin akran tercihli davranış üzerinde anlamlı yordayıcılar olmadığı görülmektedir.

Araştırmada kullanılan Öğrenci Kişisel Bilgi Formu ve Sosyal Yeterlik ve Okula Uyum Ölçeğinin alt boyutlarından biri olan "öğretmen tercihli davranış"ın yordanmasına ilişkin çoklu regresyon analizi yapılmış ve bulgular Tablo 5 'te verilmiştir.

Tablo 5. Öğretmen Tercihli Davranış Düzeyinin Yordanmasına İlişkin Çoklu Regresyon Analizi Sonuçları

\begin{tabular}{|c|c|c|c|c|c|}
\hline Değişken & B & $\begin{array}{c}\text { Standart Hata } \\
\text { B }\end{array}$ & $\beta$ & $\mathrm{t}$ & $\mathrm{P}$ \\
\hline Sabit & 38.470 & 1.921 & & 20.027 & .000 \\
\hline Travma & 1.436 & 1.423 & .074 & 1.009 & .314 \\
\hline İş birliği & -6.096 & 1.482 & -.305 & -4.113 & $.000 *$ \\
\hline Cinsiyet & -.659 & 1.375 & -.034 & -.479 & .633 \\
\hline Okul öncesi eğitim & -.793 & 1.403 & -.041 & -.565 & .573 \\
\hline
\end{tabular}

$\mathrm{R}=.33 \mathrm{R}^{2}=.11 * \mathrm{p}<.05$

Tablo 5 incelendiğinde araştırmanın bağımsız değişkenleri olan öğrencinin travmatik bir yaşantısının olup olmadığı, ailenin öğretmenle yeterince iş birliğine girip girmediği, öğrencinin cinsiyeti ve okul öncesi eğitim alıp almadığı değişkenlerinin öğretmen tercihli davranış üzerindeki varyansın \%11'ini açıkladığı görülmektedir. Standardize edilmiş regresyon katsayısına $(\beta)$ göre, öğretmen tercihli davranış düzeyi üzerindeki göreli önem sırası; iş birliği $(\beta=-.305)$, travma $(\beta=.074)$, okul öncesi eğitim $(\beta=-.041)$ ve cinsiyet $(\beta=-.034)$, olarak sıralanmaktadır. Regresyon katsayılarının anlamlılığına ilişkin $\mathrm{t}$ testi sonuçlarına bakıldığında; iş birliği $(\mathrm{t}=-4.113, \mathrm{p}<.05)$ değişkeninin öğretmen tercihli davranış üzerinde anlamlı yordayıc1 olduğu; ancak travma $(t=1.009, p>.05)$, cinsiyet $(t=-.479, p>.05)$ ve okul öncesi eğitim $(\mathrm{t}=-.565, \mathrm{p}>.05)$ değişkenlerinin akran tercihli davranış üzerinde anlamlı yordayıcılar olmadığı görülmektedir.

Araştırmada kullanılan Öğrenci Kişisel Bilgi Formu ve Sosyal Yeterlik ve Okula Uyum Ölçeğinin alt boyutlarından biri olan "okula uyum"un yordanmasına ilişkin çoklu regresyon analizi yapılmış ve sonuçlar Tablo 6' da verilmiştir.

Tablo 6. Okula Uyum Düzeyinin Yordanmasına İlişkin Çoklu Regresyon Analizi Sonuçları

\begin{tabular}{lccccc}
\hline \multicolumn{1}{c}{ Değişken } & $\mathrm{B}$ & $\begin{array}{c}\text { Standart Hata } \\
\text { Sabit }\end{array}$ & $\mathrm{B}$ & $\beta$ & $\mathrm{T}$ \\
Travma & 26.560 & 1.375 & & 19.313 & .000 \\
İş birliği & .676 & 1.019 & .050 & .664 & .508 \\
Cinsiyet & -2.653 & 1.061 & -.190 & -2.500 & $.013^{*}$ \\
Okul öncesi eğitim & -2.211 & .985 & -.165 & -2.245 & $.026^{*}$ \\
\hline
\end{tabular}

$\mathrm{R}=.26 \mathrm{R}^{2}=.070 * \mathrm{p}<.05$

Tablo 6 incelendiğinde araştırmanın bağımsız değişkenleri olan öğrencinin travmatik bir yaşantısının olup olmadığı, ailenin öğretmenle yeterince iş birliğine girip girmediği, öğrencinin cinsiyeti ve okul öncesi eğitim alıp almadığı değişkenlerinin okul uyumundaki varyansın \%07'sini açıkladığı görülmektedir. Standardize edilmiş regresyon katsayısına $(\beta)$ göre, okula uyum düzeyi üzerindeki göreli önem sırası; iş birliği $(\beta=-.190)$, cinsiyet $(\beta=-.165)$, okul öncesi eğitim $(\beta=.089)$, travma $(\beta=.050)$ olarak sıralanmaktadır. Regresyon katsayılarının anlamlılığına ilişkin $\mathrm{t}$ testi sonuçlarına bakıldığında; iş birliği $(\mathrm{t}=-2.500, \mathrm{p}<.05)$ ve cinsiyet $(\mathrm{t}=-2.245, \mathrm{p}<.05)$ değişkenlerinin okul uyum düzeyi üzerinde anlamlı yordayıcılar olduğu; travma $(\mathrm{t}=.664, \mathrm{p}>.05)$ ve okul öncesi eğitim $(\mathrm{t}=1.193, \mathrm{p}>.05)$ değişkenlerinin anlamlı yordayıcılar olmadığg görülmektedir. 


\section{Sonuç, Tartışma ve Öneriler}

$\mathrm{Bu}$ bölümde, ilkokul birinci sınıf öğrencilerinin okula uyum düzeylerini etkileyen cinsiyet, okul öncesi eğitim alıp almama durumu, ailenin öğretmenle yeterince iş birliğine girip girmemesi ve öğrencinin travmatik bir yaşantısının olup olmaması değişkenlerinin akran tercihli davranış, öğretmen tercihli davranış ve okula uyum düzeyleri için anlamlı birer yordayıcı olup olmadığına ilişkin bulgular, konuyla ilgili alanyazın 1 şığında tartışılmış ve ulaşılan sonuçlar doğrultusunda verilen öneriler yer almaktadır.

Araştırmada, cinsiyet değişkeninin akran tercihli davranış, öğretmen tercihli davranış ve okula uyum düzeyi için anlamlı yordayıcı olup olmadığına ilişkin analizler sonucunda; cinsiyetin, okula uyum düzeyi için anlamlı bir yordayıcı olduğu ancak akran tercihli davranış ve öğretmen tercihli davranış için anlamlı düzeyde yordayıcı olmadığı görülmüsstür. Literatür incelendiğinde; akran tercihli davranış, öğretmen tercihli davranış ve okula uyum düzeyi puanlarının cinsiyete göre anlamlı derecede farklılaşmadığını ifade eden araştırmalara (Akman, Topçu, Baydemir, Şahin ve Şirin, 2011; Arabacıoğlu, 2019; Arı ve Özcan, 2014; Arslan, 2016; Çıkrıkçı, 1999; Çökük, 2019; Ensar ve Keskin, 2014; Erkan, 2011; Ekinci -Vural ve Kocabaş, 2012; Erkan \& K1rca, 2010; Güler ve Onur, 2016; Güner, 2008; Özcan, 2014; Öztürk, 2008; Pears, Fisher, Bruce, Kim \&Yoerger, 2010; Tekin, 2018; Topçu, 2012; Tunçeli, 2012; Tutal, 2013; Türkyılmaz, 2018; Yoleri, 2015) rastlanmakla birlikte, puanların kızlar yönünde (Akkuş- Çutuk, 2017; Arabacıoğlu, 2019; Dirlik, 2014; Ekinci-Vural ve Kocabaş, 2012; Geçin, 2016; Granot \& Mayseless, 2001; Güler, 2016; Güler ve Onur, 2016; Işı1, 2007; Karakuş, 2008; Kaya ve Akgün, 2016; Santa Lucia, Gesten, Rendina- Gobioff, Epstein, Kaufmann, Salcedo \& Gadd, 2000; Sungur, 2010; Tutkun, 2012; Uz Baş, 2003; Yurdakavuştu, 2012), ve erkekler yönünden (Başaran, Gökmen ve Akdağ, 2014; Powers \& Bierman, 2013; Taner ve Başal, 2005) anlamlı derecede farklılaştığını ifade eden araştırmalar olduğu görülmektedir. Demirci'nin (2019) ilkokul birinci sınıf öğrencilerinin sosyal yeterlik ve okula uyumları cinsiyet değişkeni açısından incelediği araştırmada ögretmen tercihli sosyal davranış, akran tercihli sosyal davranış ve okula uyum davranışı alt boyutlarından elde edilen puanların cinsiyete göre anlamlı düzeyde farklılaşmadığı görülmüştür. Ateş (2016) ise, ilkokul birinci sınıf öğrencilerinin okula uyumlarına etki eden en düşük faktörün öğrenci cinsiyetinin olduğunu ifade etmiştir. Sonuç olarak, lirteratürde cinsiyetin akran tercihli davranış, öğretmen tercihli davranış ve okula uyum düzeyleriyle ilişkili araştırmalarda da, farklı sonuçlar elde edildiği görülmektedir. Elde edilen bulgular arasında farklılıklar olması, araştırmaların yürütüldüğü örneklem grubuna ait sosyal ve kültürel özellikler gibi birçok demografik değişkenin farklı olması ile açıklanabilir.

Araştırmada, öğrencilerin okul öncesi eğitim alma durumuna göre akran tercihli davranış, öğretmen tercihli davranış ve okula uyum düzeyi için yapılan anlamlı analizleri sonucunda; okul öncesi eğitim alma durumunun akran tercihli davranış, öğretmen tercihli davranış ve okula uyum düzeyi için anlamlı düzeyde bir yordayıcı olmadığı sonucuna ulaşılmıştır. Konuyla ilgili alanyazın incelendiğinde bu araştırmadan elde edilen bulguların aksine; okul öncesi eğitim alma durumunun akran tercihli davranış, ögretmen tercihli davranış ve okula uyum düzeyi için anlamlı bir etki ifade ettiği araştırmalar (Akbaşlı ve Üredi, 2014; Arı ve Özcan, 2014; Arslan, 2016; Atılgan 2001; Çiftçi, 2017; Çökük, 2019; Demirci, 2019; Ekinci-Vural ve Kocabaş, 2012; Ensar ve Keskin, 2014; Erkan, 2011; Erkan ve Kurca, 2010; Ertürk, 2018; Esaspehlivan, 2006; Işıkoğlu-Erdoğan ve Şimşek, 2014; Gedik, 2015; Güler, 2016; Gümüş, 2013; Kapsch, 2006; Özbek, 2003; Öztürk, 2008; Pehlivan, 2006; Sirem, 2014; Taner ve Başal, 2005; Tehci, 2018; Unutkan, 2003; Yeşil, 2008; Yoleri ve Tanış, 2014) görülmektedir. Sungur (2010) ise, okul öncesi eğitim alıp-almama durumunun akran tercihli davranış ve okula uyum düzeyi için anlamlı düzeyde bir yordayıcı olduğunu bulgularken, öğretmen tercihli davranış üzerinde anlamlı bir etkiye sahip olmadığını belirlemiştir. Erbay (2008) ve Topçu (2012) ise yaptıkları araştırmalarda okul öncesi eğitimin ilkokul birinci sınıf öğrencilerinin okula uyum ve sosyal beceri düzeyleriyle anlamlı bir ilişkisinin olduğunu bulunmuştur. Güler ve Onur (2016) ise, araştırmada okul öncesi eğitimin okula 
uyum düzeyinde anlamlı etkisinin olduğunu ifade etmiştir. Sonuç olarak, literatür incelendiğinde alan yazında okul öncesi eğitim alma durumunun akran tercihli davranış, öğretmen tercihli davranış ve okula uyum düzeyi için anlamlı düzeyde bir yordayıcı olmadığı araştırma bulgularına rastlanmamıştır. Araştırmada elde edilen bulguların alan yazındakilerden farklı olması; araştırma örneklemlerindeki ögrencilerin farklı nitelikte okul öncesi eğitim kurumlarından yararlandıkları, farklı aile ve yetiştirilme tarzı, sosyal özellikler ile farklı eğitim ortamlarından gelerek ilkokul birinci sınıfa başlamış olmalarıyla açıklanabilir.

Araştırmada ailenin öğretmenle yeterince iş birliğine girip girmediği değişkeni için akran tercihli davranış, öğretmen tercihli davranış ve okula uyum düzeyi için yapılan analizler sonucunda; ailenin öğretmenle yeterince iş birliğine girip girmemesinin akran tercihli davranış, öğretmen tercihli davranış ve okula uyum düzeyi için anlamlı yordayıcı olduğu sonucuna ulaşılmıştır. Konuyla ilgili yapılan araștırmalar incelendiğinde; bu araştırma sonucuna paralel olarak ailenin öğretmenle yeterince iş birliğine girip girmemesinin akran tercihli davranış, öğretmen tercihli davranış ve okula uyum düzeyinde anlamlı farklılık olduğunu raporlayan araştırmalar (Bekyürek, 2008; Gürşimşek, 2010; Hacısalihoğlu, Karadeniz, Aksu ve Topal, 2012; İpek, 2011; Kızıltaş, 2009; Kotaman, 2008; Özcan, 2012; Özcan ve Aydoğan, 2014; Sevinç ve Evirgen, 2003) olduğu gibi, ailenin öğretmenle yeterince iş birliğine girip girmemesinin akran tercihli davranış, öğretmen tercihli davranış ve okula uyum düzeyi üzerinde anlamlı farklılık olmadığını belirten araştırmalara da (Zorbaz, 2016) rastlanmaktadır. Alan yazında ve bu araştırmada elde edilen bulgular genel olarak değerlendirildiğinde ailenin öğretmenle yeterince iş birliğine girip girmemesinin akran tercihli davranış, öğretmen tercihli davranış ve okula uyum düzeyi üzerinde anlamlı ilişki olduğu yönündeki sonuçlar ağırlıktadır. Bu konuda Baughan (2012) ilkokula geçiş döneminde olan çocukların okula uyumlarını incelediği bir araştırmada, ebeveynin çocuğun okul ve akademik hayatına katılımının ve ebeveyn tatminin çocuğun okul uyumunun yordayıcıları olduğu, Çelenk (2003) tarafından yapılan bir araştırmada aile katılımının çocuğun okul başarısını olumlu yönde etkilediği ve Şeker (2009) tarafından yapılan bir başka araştırmada da velilerin çocuklarının eğitimine katılımları ile çocuklarının okuldaki başarıları arasında pozitif ilişki olduğu tespit edilmiştir. Bu durum, öğrencilerin okula uyum sürecinde ailenin öğretmenle iş birliğine girmesinin öğrencinin okula uyumunu etkileyen, öğretmene, öğrenmeye ve okula ilişkin olumlu tutum kazanması gibi birçok konuda ailenin rolleriyle ilişkili olmasıyla ile açıklanabilir.

Araştırmada, öğrencinin travmatik bir yaşantısının olup olmadığı değişkeninin akran tercihli davranış, öğretmen tercihli davranış ve okula uyum düzeyi için anlamlı yordayıcı olup olmadığına ilişkin analizler sonucunda; öğrencinin travmatik bir yaşantısının olup olmama durumunun, öğretmen tercihli davranış ve okula uyum düzeyi için anlamlı düzeyde yordayıcı olmadığı ancak akran tercihli davranış için anlamlı bir yodayıcı olduğu bulgulanmıştır. Öğrencinin travmatik bir yaşantısının olup olmadığ 1 değişkeninin akran tercihli davranış, öğretmen tercihli davranış ve okula uyum düzeyi üzerindeki etkisini inceleyen literatürdeki araştırmalar arasında anlamlı ilişki olduğu yönünde sonuca ulaşan araştırma (Dilmenler, 2019) bulunmaktadır. Alanyazın tekrar incelendiğinde, öğrencinin travmatik bir yaşantısının olup olmama durumunun anlamlı farklılık ifade etmediğini (Okutan, 2017) bulgulayan araştırmalara da rastlanmaktadır. $\mathrm{Bu}$ araştırmada elde edilen bulguların alanyazında incelenen araştırmaların bulgularından farklı olması yönündeki sonuç; söz konusu travmatik deneyimin ne olduğuna, travma algısına ve çocuğun içinde bulunduğu sosyal destek mekanizmalarına bağlı olarak farklılaşabileceğiyle açıklanabilir.

Araştırmanın bulgularından elde edilen sonuçlara dayalı olarak şu önerilerde bulunulabilir:

\section{Araştırmacılara Yönelik Öneriler}

1. Bu araştırmada cinsiyetin okula uyum düzeyi üzerinde anlamlı yordayıcı olduğu ancak akran tercihli davranış ve öğretmen tercihli davranış için anlamlı düzeyde yordayıcı olmadığı bulgulanmıştır. 
Bu nedenle okula uyumun bir yordayıcı olarak cinsiyetin, farklı sosyal ve kültürel özelliklere sahip daha büyük örnekleme sahip araştırmalar yapılması,

2. Araştırmada okul öncesi eğitim alma değişkeninin okula uyumun bir yordayıcısı olmadığı bulunmuştur. İlkokula başlayan öğrencilerin okul öncesi eğitim aldıkları sosyal çevre özelliklerine göre farklılaşmasını ele alan karşılaştırmalı araştırmalar yapılması, hatta okula uyum güçlüğü yaşayan öğrencilerin okul öncesi dönemden ilkokul dördüncü sınıfa kadar uyum düzeylerinin ne yönde değiştiğine ilişkin boylamsal çalışmalar yapılması,

3. İlkokul birinci sınıf öğrencilerinin ailelerinin öğretmenle iş birliğine girmesinin okula uyum düzeylerinin bir yordayıcısı olduğu sonucuna ulaşılmıştır. Aileyle öğretmen arasındaki iş birliğinin niteliğini etkileyen faktörlerin (öğretmen tutumu, anne-baba tutumu, iletişim biçimi vb) incelendiği araştırmalar yapılması,

4. Öğrencinin travmatik bir yaşantısının olup olmaması durumunun, öğretmen tercihli davranış ve okula uyum düzeyi için anlamlı düzeyde yordayıcı olmadığı ancak akran tercihli davranıș için anlamlı bir yordayıc1 olduğu sonucuna ulaşılmıştır. Öğrencinin travma deneyiminin nitel verilerle de desteklenerek daha ayrıntılı olarak ele alan araştırmalar yapılması önerilmektedir.

\section{İlkokul Birinci Sınıf Öğretmenlerine Yönelik Öneriler}

1. İlkokul birinci sınıf öğretmenlerinin, oryantasyon haftasında uyum problemi yaşayan öğrencileri gözlem, görüşme vb veri toplama araçlarını kullanarak uyumsuzluk yaşayabilecek öğrencileri belirlemeye çalışması (risk grubu öğrencilerinin belirlenmesi) sürece katkı sağlayabilir (önleyicilik). Sürecin başından itibaren önleyici çalışmalar kapsamında aile ile iş birliğini sürdürerek uyum sorunlarına yönelik çalışmalarını başlatabilir.

2. Okula uyumu etkileyen bireysel farklılıkları belirleyerek, öğrencilerin uyumunu kolaylaştırıcı etkinlikleri zenginleştirmeleri,

3. Okula uyum sürecinde önemli bir faktör olarak, akran ilişkilerinin de sürece dahil edilebileceği çalışmalar yürütmeleri önerilmektedir.

\section{Ailelere Yönelik Öneriler}

4. Okula uyum güçlüğü yaşayan öğrenci velisi gerekli müdahaleleri yapmak ve uygun davranışlar sergileyebilmek için sınıf öğretmeni ve rehberlik servisi ile iş birliği yapabilir.

5. Okula uyumu kolaylaştırmaya yönelik olarak çocuğunun, özdenetim, sorumluluk bilinci, iletişim becerilerini destekleyen, çocuğuna güvenen ve koşulsuz kabul ile yetiştiren ebeveyn tavırları sergilenebilir. 


\section{Kaynakça}

Akay, D., ve Ceylan, R. (2019). İlkokula hazırbulunuşluğun değerlendirilmesi. D. Yalman ve M. Ü. Öztabak (Ed.), Okula uyum ve erken okuryazarlık eğitimi içinde (s. 157-172). İstanbul: Efe Akademi.

Akbaşl1, S. ve Üredi, L. (2014). An evaluation of the classroom teachers,, attitudes towards the constructivist approach according to complexity theory: A case of Mersin. In Chaos, Complexity and Leadership (419-434). Springer, Cham.

Akkuş-Çutuk, Z. (2017). 5. Sınıf öğrencilerinin sosyal becerilerinin özsaygı ve denetim odağı ile ilişkisi. Abant İzzet Baysal Üniversitesi Ë̆itim Fakültesi Dergisi, 17(2), 505-525.

Akman, B., Topçu, Z., ve Baydemir, G. Şahin. S, ve Şirin, E. (2011). Altı yaş grubu çocukların sosyal becerilerinin oyun arkadaşı tercihleri üzerindeki etkisi. Journal of New World Sciences Academy Education Sciences, 6(2), 1548-1560.

Arabacıoğlu, B. (2019). Okul öncesi dönem çocuklarının okula uyum düzeyleri ile ebeveyn tutumları ve çocuğun mizaç özellikleri arasındaki ilişkinin incelenmesi. Yayınlanmamış yüksek lisans tezi. Uludağ Üniversitesi Eğitim Bilimleri Enstitüsü, Bursa.

Arı, A., ve Özcan, E. (2014). Birinci sınıf öğrencilerinin okul olgunluğu düzeylerinin, okuma yazmayı öğrenmelerine etkisi. Dumlupınar Üniversitesi Sosyal Bilimler Dergisi, (47), 74-90.

Arslan, A. (2016). Illkokul birinci sınıf ögrencilerinin sosyal becerilerinin incelenmesi. Yayınlanmamış yüksek lisans tezi. Giresun Üniversitesi Sosyal Bilimler Enstitüsü, Giresun.

Ateş, E. Ş. (2016). Sinıf öğretmenlerinin, ilkokul 1. sinıfa devam eden öğrencilerin okula uyumuna ilişkin görüşleri. Yayımlanmamış yüksek lisans tezi. Gazi Üniversitesi Eğitim Bilimleri Enstitüsü, Ankara.

Atılgan, G. (2001). Okul öncesi eğitim kurumlarına devam eden ve etmeye ilköğretim I. kademe ve I. devre ögrencilerinin sosyal beceri özelliklerinin karşılaştırılması. Yayınlanmamış yüksek lisans tezi Selçuk Üniversitesi Sosyal Bilimler Enstitüsü, Konya.

Bartan, M. (2019). Okul öncesi eğitim programında ilkokula hazırlık. D. Yalman ve M. Ü. Öztabak (Ed.), Okula uyum ve erken okuryazarlık eğitimi içinde (s. 125-151). İstanbul: Efe Akademi.

Başaran, S., Gökmen, B., \& Akdağ, B. (2014). Okul öncesi öğrencilerinin okula uyum sürecinde öğretmenlerin karşılaştığı sorunlar ve çözüm önerileri. Uluslararası Türk Ĕ̈itim Bilimleri Dergisi, 2(2), 197-222.

Baştuğ, M., ve Hiğde, A. (2019). İlkokul dönemi, temel özellikleri, ilkokul 1. sınıf programı. Ö. Polat (Ed.), Okula uyum ve erken okuryazarlık eğitimi içinde (s. 83- 104). Ankara: Anı yayıncılık.

Baughan, C. C. (2012). An examination of predictive factors related to school adjustment for children with disabilities transtioning into formal settings. Unpublished dissertation. The Graduate School of Clemson University, Clemson.

Bekyürek, O. (2008), İlköğretim okulu yöneticilerinin öğrenci velileriyle iletişimde karsılaştıkları sorunlar istanbul ili bahçelievler ilçesi örneği, Yayınlanmamış yüksek lisans tezi. Beykent Üniversitesi Sosyal Bilimler Enstitüsü, İstanbul.

Büyüköztürk, Ş. (2012). Sosyal bilimler için veri analizi el kitabı. Ankara: Pegem Akademi Yayıncılık. 
Canbulat, T. (2007). Kesintili zorunlu eğitimden etkilenen ilkokul birinci sınıf öğrencilerinin okula uyum ve okula hazır bulunuşluk düzeylerinin değerlendirilmesi. Kastamonu Ĕ̆itim Dergisi, 25(4), 1573-1586.

Çelenk, S. (2003). Okul-aile iş birliği ile okuduğunu anlama arasındaki ilişki. Hacettepe Üniversitesi Eğitim Fakültesi Dergisi, 24, 3-39.

Çıkrıkçı, S. (1999). Ankara il merkezinde resmi banka anaokullarına devam eden 5-6 yaş çocuklarının okul olgunluğu ile aile tutumu arasındaki ilişkinin incelenmesi. Yayınlanmamış yüksek lisans tezi. Gazi Üniversitesi Sosyal Bilimler Enstitüsü, Ankara.

Çiftçi, E. (2017). Birinci sınıfa kayıtl farklı yaş grubundaki ögrencilerin türkçe ve matematik dersi ögretim programına dair kazanımlara ulaşma durumlarının incelenmesi. Yayımlanmamış yüksek lisans tezi. Gaziantep Üniversitesi Eğitim Bilimleri Enstitüsü, Gaziantep.

Çokluk, Ö. S., Şekercioğlu, G. ve Büyüköztürk, S. (2012). Sosyal bilimler için çok değişkenli istatistik: spss ve lisrel uygulamalarl. Ankara: Pegem Akademi Yayıncılık.

Çökük, K. (2019). Farklı yaşlarda ilkokula başlayan öğrencilerin okula hazırbulunuşlukları ve uyum sorunları. Yayınlanmamış yüksek lisans tezi. Van Yüzüncü Yıl Üniversitesi Eğitim Bilimleri Enstitüsü, Van.

Demirci, E. (2019). İlkokul birinci sınıf öğrencilerinin sosyal becerileri ve okula uyum durumlarının çeşitli değişkenler açısından incelenmesi. Yayınlanmamış yüksek lisans tezi. Selçuk Üniversitesi Sosyal Bilimler Enstitüsü, Konya.

Deniz, S. (2016). İlkokul öğrencilerinin demografik özellikleri ile akademik başarıları arasındaki ilişkinin incelenmesi. Yayınlanmamış yüksek lisans tezi. Fırat Üniversitesi Eğitim Bilimleri Enstitüsü, Elazı ğ.

Dilmenler, H. (2019). Ebeveyn ve birincil bakım verenleri tarafindan travma yaşadığı belirtilen ve belirtilmeyen çocuklarda travma sonrası duygusal stres ile dikkat eksikliği, hiperaktivite, dürtüsellik, karşı gelme sorunları ve davranım sorunları arasındaki ilişki. Yayınlanmamış yüksek lisans tezi. Üsküdar Üniversitesi Sosyal Bilimler Enstitüsü, İstanbul.

Dirlik, C. (2014). 4+4+4 Ĕ̈itim sisteminde 60-66 aylık öğrencilerin okula hazır bulunuşlukta sosyal uyum düzeylerinin incelenmesi. Yayınlanmamış yüksek lisans tezi. İstanbul Aydın Üniversitesi Sosyal Bilimler Enstitüsü, İstanbul.

Ekinci-Vural, D. ve Kocabaş, A. (2012). İlköğretim 1. sınıf öğrencilerinde sosyal becerilerin çeşitli değişkenler açısından incelenmesi. Trakya Üniversitesi Ĕ̆itim Fakültesi Dergisi, 2(1), 29-46.

Ensar, F. ve Keskin, U. (2014). İlkokul birinci sınıf öğrencilerinin okula uyumları üzerine bir inceleme. Eğitimde Kuram ve Uygulama, 10(2), 459-477.

Erbay, E. (2008). Okul öncesi eğitim alan ve almayan ilköğretim birinci sinıf ögrencilerinin sosyal becerilere sahip olma düzeyleri. Yayınlanmamış yüksek lisans tezi. Pamukkale Üniversitesi Sosyal Bilimler Enstitüsü, Denizli.

Erkan, S. (2011). Farklı sosyoekonomik düzeydeki ilköğretim birinci sınıf öğrencilerinin okula hazır bulunuşluklarının incelenmesi. Hacettepe Üniversitesi Eğitim Fakültesi Dergisi, 40(40), 186-197.

Erkan, S. ve Kırca, A. (2010). Okul öncesi eğitimin ilköğretim birinci sınıf öğrencilerinin okula hazırbulunuşluklarına etkisinin incelenmesi. Hacettepe Üniversitesi Eğitim Fakültesi Dergisi, (38), 94-106. 
Ertürk, Ç., (2018). Çocuklarda okul öncesi eğitimin el fonksiyonu üzerine etkisi. Yayınlanmamış yüksek lisans tezi. Bahçeşehir Üniversitesi Sağl1k Bilimleri Enstitüsü, İstanbul.

Esaspehlivan, M. (2006). Okul öncesi eğitim kurumuna gitmiş ve gitmemiş 78 ve 68 aylı çocukların okula hazır bulunuşluklarının karşılaştırılması. Yayımlanmamış yüksek lisans tezi. Marmara Üniversitesi Eğitim Bilimleri Enstitüsü, İstanbul.

Geçin, G. (2016). 5-6 yaş çocukların bağlanma durumları ile okul uyum düzeyleri arasındaki ilişkinin incelenmesi. Yayınlanmamış yüksek lisans tezi. Çukurova Üniversitesi Sosyal Bilimler Enstitüsü, Adana.

Gedik, S. (2015). Öğretmen algılarına göre 60-66 aylık çocuklarda okula uyumun incelenmesi (Fatih ilçesi örneği). Yayımlanmamış yüksek lisans tezi. Yeditepe Üniversitesi, İstanbul.

Granot, D., \& Mayseless, O. (2001). Attachment security and adjustment to school in middle childhood. International Journal of Behavioral Development, 25(6), 530-541.

Güler, H. (2016). İlkokul 1. sınıfa başlayan öğrencilerin okula başlama yaşına göre okula uyumlarının ve okuma-yazma becerilerinin incelenmesi. Yayınlanmamış yüksek lisans tezi. Giresun Üniversitesi Sosyal Bilimler Enstitüsü, Giresun.

Güler, H. ve Onur, M. (2016). İlkokul 1. sınıfa başlayan öğrencilerin okula başlama yaşına göre okula uyumlarının incelenmesi. 21. Yüzyllda Eğitim ve Toplum Eğitim Bilimleri ve Sosyal Araştırmalar Dergisi, 5(14), 87-109.

Gümüş, S. (2013). 1. sınıfa başlama yaşının değerlendirilmesi. Öğretmen Dünyası,34(402), 7-8.

Güner, A. Z. (2008). Eğitici drama uygulamalarının 5-6 yaş grubu çocukların sosyal- duygusal uyumlarına etkisinin incelenmesi. Yayımlanmamış yüksek lisans tezi. Marmara Üniversitesi Sosyal Bilimler Enstitüsü, İstanbul.

Gürşimşek, I. (2010). Okul öncesi eğitime aile katılımını etkileyen faktörler. Eğitim Bilimleri ve Uygulama, 9(18), 1-19.

Hacısalihoğlu, Karadeniz, M., Aksu, H. H. ve Topal, T. (2012). Aile katılım sürecinin ilköğretim birinci kademe öğrencilerinin matematik başarısına yansımaları, Milli Ĕ̆itim, 196, 232-245.

Işık, M. (2007). Anasınıfina devam eden beş-altı yaş çocuklarına sosyal uyum ve beceri ölçeğinin uyarlanması ve uygulanması. Yayımlanmamış yüksek lisans tezi. Gazi Üniversitesi Eğitim Bilimleri Enstitüsü, Ankara.

Işıkoğlu-Erdoğan, N., ve Şimşek, Z. C. (2014). Birinci sınıfa başlayan çocukların, velilerin ve öğretmenlerin okula uyumlarının incelenmesi. International Journal of New Trends in Arts, Sports \& Science Education, 3(2).

İpek, C., (2011). Velilerin okul tutumu ve eğitime katılım düzeyleri ile aileye bağlı bazı faktörlerin ilköğretim öğrencilerinin seviye belirleme sinavları üzerine etkisi. Pegem Ĕ̈itim Ö̆̆retim Dergisi, 1(2).

Kapsch, L.A. (2006). The effect of dramatic play on children's graphic representation of emotion. $\mathrm{Ph} . \mathrm{D}$ Thesis, Georgia State University, Atlanta.

Karakuş, A. (2008). Okul öncesi sosyal davranış ölçeği öğretmen formu’nun güvenirlik ve geçerlik çalışması. Yayınlanmamış yüksek lisans tezi. Marmara Üniversitesi Eğitim Bilimleri Enstitüsü, İstanbul. 
Kaya, Ö. S., ve Akgün, E. (2016). Okul öncesi dönemdeki çocukların okula uyum düzeylerinin çeşitli değişkenler açısından incelenmesi. İlköğretim Online, 15(4), 1311-1324.

K1lıç, R., ve Gedik, O. (2019). Illköğretimin özellikleri ve ilköğretim programları. İçinde. Okula uyum ve erken okuryazarlık eğitimi (s. 179-204). İstanbul: Efe Akademi.

Kızıltaş, E. (2009). Okul öncesi eğitimde uygulanan aile katılım çalışmalarının 5-6 yaş grubu çocukların dil becerilerinin gelişimine etkisi. Yayınlanmamış yüksek lisans tezi. Atatürk Üniversitesi Sosyal Bilimler Enstitüsü, Erzurum.

Kotaman, H. (2008). Türk ana babalarının çocuklarının eğitim öğretimlerine katılım düzeyleri. Uludă̆ Üniversitesi Ë̆itim Fakültesi Dergisi, 21(1), 135-149.

Okutan, S. B. (2017). Riskli davranış gösteren ergenlerde, çocukluk çağı travmalarının ruhsal belirtilerle ilişkisi. Yayınlanmamış yüksek lisans tezi. İstanbul Ticaret Üniversitesi Sosyal Bilimler Enstitiüsü, İstanbul.

Özbek, A. (2003). Okulöncesi eğitim kurumlarına devam eden ve etmeyen çocukların ilköğretim birinci sınıfta sosyal gelişim açısından öğretmen görüşüne dayalı olarak karşılaştırılması. Yayınlanmamış yüksek lisans tezi. Eskişehir Anadolu Üniversitesi Eğitim Bilimleri Enstitüsü, Eskişehir.

Özcan, Ç. (2012). Okul öncesinde aile katılımı ile çocukların akademik benlik saygısı düzeyi arasındaki ilişkinin anne-baba görüşlerine göre incelenmesi. Yayınlanmamış yüksek lisans tezi. Abant İzzet Baysal Üniversitesi, Bolu.

Özcan, Ç., ve Aydoğan, Y. (2014). Aile katılımı ile çocukların akademik benlik saygısı arasındaki ilişkinin anne-baba görüşlerine göre incelenmesi, Milli Eğitim, 202, 19- 36.

Özcan, E. (2014). Birinci sınıf ögrencilerinin bilişsel okul olgunluğu düzeylerinin okuma yazmayı ögrenme sürecine olan etkisi. Yayımlanmamış yüksek lisans tezi. Eskişehir Osmangazi Üniversitesi Eğitim Bilimleri Enstitüsü, Eskişehir.

Öztabak, M. Ü. (2019). Okul öncesi çocukların okula uyumları. D. Yalman ve M. Ü. Öztabak (Ed.), Okula uyum ve erken okuryazarlı eğitimi içinde (s. 1-20). İstanbul: Efe Akademi.

Öztürk, A. (2008). Okulöncesi ĕgitimin ilköğretim 1. ve 3. sinıf ögrrencilerinin sosyal becerilerine etkisinin incelenmesi. Yayınlanmamış yüksek lisans tezi. Selçuk Üniversitesi Sosyal Bilimler Enstitüsü, Konya.

Pears, K. C., Fisher, P. A., Bruce, J., Kim, H. K., \& Yoerger, K. (2010). Early elementary school adjustment of maltreated children in foster care: The roles of inhibitory control and caregiver involvement. Child development, 81(5), 1550-1564.

Pehlivan, D. (2006). okul öncesi eğitim alan ve almayan ögrencilerin ilk okuma yazmaya geçiş sürecinin, öğretmen ve ögrenci görüşleri doğrultusunda değerlendirilmesi. Yayınlanmamış yüksek lisans tezi. Çukurova Üniversitesi Sosyal Bilimler Enstitüsü, Adana.

Polat, Ö., ve Akyol, N. A. (2019). Okula uyum ve ilkokula hazırbulunuşluk. A. Oktay (Ed.), Okula uyum ve erken okuryazarlık eğitimi içinde (s. 1-25). Ankara: Anı Yayıncılık.

Powers, C. J., \& Bierman, K. L. (2013). The multifaceted impact of peer relations on aggressivedisruptive behavior in early elementary school. Developmental psychology, 49(6), 1174.

Ryan, D.-J. (2001). Bronfenbrenner's ecological systems theory. Retrieved January, 9, 2012. 
Santa Lucia, R. C., Gesten, E., Rendina-Gobioff, G., Epstein, M., Kaufmann, D., Salcedo, O., \& Gadd, R. (2000). Children's school adjustment: A developmental transactional systems perspective. Journal of Applied Developmental Psychology, 21(4), 429-446.

Sevinç, M. ve Evirgen, Ş. (2003). Küçükçekmece okul öncesi eğitim merkezinde verilen okul destekli anne eğitim programının anneler üzerindeki etkileri Omep 2003 Dünya Konsey Toplantısı ve Konferans1 Bildiri Kitabı. Cilt:2. Ankara:Ya-Pa Yayınları.

Sirem, Ö. (2014). 4+4+4 Okul sisteminde sinıf ögretmenlerinin ilkokuma yazma ögretim sürecine yönelik görüşleri (Düzce ili örneği). Yayımlanmamış yüksek lisans tezi. Düzce Üniversitesi Sosyal Bilimler Enstitüsü, Düzce.

Sungur, G. (2010). Illköğretim birinci sınıfa devam eden çocukların sosyal uyum ve becerilerinin incelenmesi. Yayınlanmamış yüksek lisans tezi. Selçuk Üniversitesi Sosyal Bilimler Enstitüsü, Konya.

Şeker, M. (2009). İlköğretim 5. sını öğrencilerinin performans görevlerindeki başarıları ile ailelerinin eğitim-öğretim çalışmalarına katılım düzeyleri arasındaki ilişkinin belirlenmesi. Yayımlanmamış yüksek lisans tezi. Çukurova Üniversitesi Sosyal Bilimler Enstitüsü, Adana.

Taner, M., ve Başal, H. A. (2005). Farklı sosyoekonomik düzeylerde okulöncesi eğitimi alan ve almayan ilköğretim birinci sınıf öğrencilerinin dil gelişimlerinin cinsiyete göre karşılaştırılması. Uludă̆ Üniversitesi Ĕ̈itim Fakültesi Dergisi, 18(2), 395- 420.

Taşçı, M. (2013). 5-7 yaş grubundan oluşan 1. sınıftaki öğrencilerin sosyal becerilerinin değerlendirilmesi. Yayınlanmamış yüksek lisans tezi. İstanbul Aydın Ünivesitesi Sosyal Bilimler Enstitüsü, İstanbul.

Tehci, A., (2018). Okul öncesi eğitimin ilk okuma ve yazma başarısına etkisi. Yayınlanmamış yüksek lisans tezi. Bayburt Üniversitesi Sosyal Bilimler Enstitüsü, Bayburt.

Teke, H. (2010). Ana sınıfi ögrretim programının ilköğretim 1. kademe 1. sinıf ögrencilerinin hazırbulunuşluk düzeylerine etkisinin ögretmen görüşlerine göre incelenmesi. Yayınlanmamış yüksek lisans tezi. Selçuk Üniversitesi Sosyal Bilimler Enstitüsü, Konya.

Tekin, H. (2018). Öz düzenleme becerilerinin ilkokula hazırbulunuşluk üzerindeki etkisi. Yayımlanmamış yüksek lisans tezi. Adnan Menderes Üniversitesi Sosyal Bilimler Enstitüsü, Aydin.

Topçu, Z. (2012). Okul öncesi eğitimin ilköğretim birinci sinıf ögrencilerinin okula uyum ve türkçe dil becerilerine etkisinin incelenmesi. Yayımlanmamış yüksek lisans tezi. Hacettepe Üniversitesi Sosyal Bilimler Enstitüsü, Ankara.

Tuğluk, M. N., ve Ayhan, M. (2019). İlkokula hazır oluş ve hazır oluşu etkileyen faktörler. D. Yalman ve M. Ü. Öztabak (Ed.), Okula uyum ve erken okuryazarlık ĕgitimi içinde (s. 105-120). İstanbul: Efe Akademi.

Tuna, A., ve Kaçar, A. (2005). İlköğretim matematik öğretmenliği progamına başlayan öğrencilerin lise 2 matematik konularındaki hazır bulunuşluk düzeyleri. Kastamonu Eğitim Dergisi, 13(1), 117 128.

Tunçeli, H. İ. (2012). Anaokullarına devam eden 6 yaş çocuklarının sosyal becerilerinin okul olgunluklarına etkilerinin incelenmesi. Yayınlanmamış yüksek lisans tezi. Hacettepe Üniversitesi Sosyal Bilimler Enstitüsü, Ankara. 
Tutal, Ö. (2013). Okuma-Yazma öğrenmede okula başlama yaşının okuma-yazma başarısına etkisi. Yayımlanmamış yüksek lisans tezi. Dicle Üniversitesi Eğitim Bilimleri Enstitüsü, Diyarbakır.

Tutkun, C. (2012). 60-72 aylık çocukların sosyal becerilerinin anne ve öğretmen değerlendirmelerine göre incelenmesi. Yayınlanmamış yüksek lisans tezi. Ankara Üniversitesi Eğitim Bilimleri Enstitüsü, Ankara.

Türkyılmaz, M.İ. (2018). İlkokul 1. sını öğrencilerinin sosyal yeterlik ve hazırbulunuşluk becerilerinin incelenmesi. Yayımlanmamış yüksek lisans tezi. Amasya Üniversitesi Sosyal Bilimler Enstitüsü, Amasya.

Unutkan. Ö. P. (2003). Marmara ilköğretime hazır oluş ölçeğinin geliştirilmesi ve standardizasyonu. Yayınlanmamış doktora tezi. Marmara Üniversitesi Eğitim Bilimleri Enstitüsü, İstanbul.

Uz Baş, A. (2003). İlköğretim 4. ve5. siniflarda okuyan öğrencilerin sosyal becerilerivle okul uyumu ile deprsyon düzeyleri arasındaki ilişkinin incelenmesi, Yayınlanmamış doktora tezi. Dokuz Eylül Üniversitesi Eğitim Bilimleri Enstitüsü. İzmir.

Yeşil, D. (2008). Okulöncesi eğitim almış ve almamış öğrencilerin okula uyumlarının karşılaştırılması. Yayımlanmamış yüksek lisans tezi. Yeditepe Üniversitesi Sosyal Bilimler Enstitüsü, İstanbul.

Yoleri, S. (2015). Preschool children's school adjustment: indicators of behaviour problems, gender, and peer victimisation. Education 3-13, 43(6), 630-640.

Yoleri, S. ve Tanış, H. M. (2014). İlkokul birinci sını f öğrencilerinin okula uyum düzeylerini etkileyen değişkenlerin incelenmesi, Karabük Üniversitesi Sosyal Bilimler Enstitüsü Dergisi, 4(2) 130-141.

Yurdakavuştu, Y. (2012). İlköğretim öğrencilerinde duygusal zeka ve sosyal beceri düzeyleri. Yayınlanmamış yüksek lisans tezi. Dokuz Eylül Üniversitesi Eğitim Bilimleri Enstitüsü, İzmir.

Zorbaz, S. D. (2016). İlkokul birinci sınıf ögrencilerinin okula uyumu: bir model testi. Yayınlanmamış doktora tezi. Hacettepe Üniversitesi Lisansüstü Eğitim-Öğretim ve Sınav Yönetmeliğinin Eğitim Bilimleri Anabilim Dalı, Ankara. 